Article

\title{
Empirical Relationships among Technological Characteristics, Global Orientation, and Internationalisation of South Korean New Ventures
}

\author{
Junghyun Yoon ${ }^{1}$ and Dae-su Kim ${ }^{2, *}$ \\ 1 POSTECH Entrepreneurship Centre, POSTECH, Pohang 37673, Korea; jyoon071121@postech.ac.kr \\ 2 School of Business, Yeungnam University, Gyeongsan 38541, Korea \\ * Correspondence: kdsduck@ynu.ac.kr; Tel.: +82-54-279-8455
}

Academic Editor: Tan Yigitcanlar

Received: 31 August 2016; Accepted: 25 November 2016; Published: 3 December 2016

\begin{abstract}
International new ventures (INVs) that pursue rapid internationalisation have received a growing amount of attention worldwide. This study, therefore, examined characteristics of INVs, and hence investigated empirically the relationships among the technological characteristics of INVs, the characteristics of their chief executive officers (CEOs) (i.e., global orientation), and their internationalisation such as the level of internationalisation. The findings of this study can be summarised as follows: all of the technological characteristics (e.g., technological capacity, imitation, innovation, and standardisation) have significant effects on the internationalisation of INVs. Furthermore, the CEO's global orientation mediated the relationship between the technological characteristics and internationalisation.
\end{abstract}

Keywords: international new ventures; internationalisation; technological characteristics; global orientation

\section{Introduction}

This study aims to explore the role of the chief executive officers (CEOs)' global orientation ("the intention of penetrating international market" [1]) in determining internationalisation. It is particularly important for small- and medium-sized enterprises (SMEs) that aspire to sell their products at the global scale. The most general theory explaining companies' internationalisation processes is the stage theory of internationalisation designed by Johanson and Vahlne [2]. According to this theory, the internationalisation of companies is triggered by an increase in the accumulated knowledge about international markets and institutions. In recent years, numerous studies $[1,3,4]$ have attempted to explain the internationalisation process of "born global firms", or international new ventures (INVs) ("a business organization that, from inception, seeks to derive significant competitive advantage from the use of resources and the sale of outputs in multiple countries" ([5], p. 49)). INVs tend to pursue globalisation as soon as they are founded [6]. In other words, INVs are companies that have plans to conduct their business globally at the time of their founding.

Traditionally, many scholars [2,7] have investigated exporters' behaviours using the incremental internationalisation model, but this model cannot fully explain the internationalisation process of INVs $[6,8]$. In order to elucidate the unique internationalisation process of INVs, some researchers $[9,10]$ have begun to employ a new model known as the "rapid internationalisation theory". Extensive studies on internationalisation have focused on the characteristics of INVs [11]. Nevertheless, few studies, based on INVs, have been carried out in South Korea. Actually, rapid internationalisation is a particularly important survival strategy in South Korea, an export-oriented country. 
Most INVs are technology-intensive SMEs. Thus, they aggressively penetrate international markets by utilising their technological characteristics such as technological capacity, imitation, innovation, and standardization (technological capacity is the ability to produce and provide innovative, leading, and distinguished goods and services while covering R\&D costs; technological imitation is the extent to which a firm's output can be imitated or copied by competitors; technological innovation is how rapidly an INV is able to produce new or innovative goods and services; and technological standardisation is the possession of domestic and international certificates and the means by which an INV standardises its technology). This strategy implies that high-technology SMEs, including INVs, tend to survive by finding new global markets [12]. In addition to these findings, several studies $[1,13]$ have reported a significant correlation between certain characteristics (e.g., global orientation) of the top management team, CEO, or founders and the rapid internationalisation process. Therefore, the CEOs' characteristics such as global orientation must be considered when investigating the internationalisation process. For example, although an INV may have superior technologies and capabilities, rapid internationalisation may not be easy due to the psychological distance and anxiety related to advancing into unknown countries. However, CEOs with international experience and stronger language capacity relating to their global target markets will take the necessary steps to internationalise more quickly [14]. The above studies demonstrate that the CEO's global orientation is one of the most important variables determining the pace of internationalisation [15]. Nonetheless, relatively few studies have conducted a detailed analytical explanation on this new phenomenon, namely the internationalisation process of INVs [1]. Therefore, more empirical studies able to explain the rapid internationalisation process of INVs need to be carried out.

As mentioned above, in South Korea, INVs might play an important role in improving its competitiveness regarding its status as an export-led country. Therefore, systemic research on the characteristics of INVs is needed. Furthermore, the number of INVs being founded is increasing [12]. In this context, this study would like to explore the characteristics of INVs by empirically investigating the relationships among technological characteristics of INVs, CEOs' global orientation, and internationalisation.

\section{Literature Review and Hypotheses}

\subsection{Definition and Characteristics of International New Ventures}

INVs are receiving a great deal of attention from scholars exploring various types of internationalisation processes [16]. The general definition of INVs was suggested by Oviatt and McDougall [17]: "a business organization that, from inception, seeks to derive significant competitive advantage from the use of resources and the sale of outputs in multiple countries". This definition indicates that one of the most significant features of INVs is to enter into international markets naturally by committing useful resources such as raw materials, workforce, or financing from multiple countries. In addition to the above studies, others have defined an INV as a firm that seeks to improve its performance by finding an international market and then selling its products and services [15]. In contrast to these studies, Madsen and Servais [18] suggested a more detailed definition of INVs as firms that "export $75 \%$ of their total sales, starting after less than two years of operation" ([18], p. 564). Although there are minor distinctions among the previous studies regarding INVs, the authors' conceptual definitions of INVs are similar. However, there are a variety of operational definitions according to researchers' research purposes, that is, there are various standards to define INVs. For instance, some authors $[19,20]$ have proposed the timing of an INV's penetration into global markets as a criterion, whereas others [21] suggested the number of international markets entered or the international sales as a criterion. However, these criteria are extremely limited in their ability to accurately measure international sales, especially when using surveys [22]. Therefore, this study proposes defining INVs based on their speed of internationalisation, namely, as "companies that find international markets after less than six years of operation" [23]. 
According to some studies of internationalisation [21,24], there are four common factors that promote the rapid internationalisation of INVs: new types of global markets for SMEs including niches, technological advancements in the areas of manufacturing, transportation, and communication, the increasing importance of global networks and cooperation, and the entrepreneurs' characteristics, who seek entry into new global markets, such as global orientation. These are the primary factors affecting the internationalisation of SMEs [11]. Interestingly, the studies on internationalisation have focused on technology-intensive start-ups. Researchers who focus on technology-intensive start-ups [25] argued that globalisation is a phenomenon propelled by high-technology industries. In contrast, studies focusing on more general groups of businesses, including low-technology SMEs [12], suggested that the characteristics of globalisation must be investigated. The studies have contributed to a debate concerning whether INVs are a new phenomenon that can explain globalisation in high-technology sectors (e.g., biotechnology and computer software) or whether they can be explained by the more traditional gradual internationalisation theory [26].

Other researchers studying the internationalisation of INVs have focused on the determinants of internationalisation and the relationships among those determinants, internationalisation, and organisational performance [11]. Finally, comprehensive research on the internationalisation of INVs has been conducted by Rialp et al. [11], Bailetti [27], and Lee and Park [23]. These researchers have focused on CEOs' characteristics such as their orientation towards and experiences in globalisation.

\subsection{Relationships between Technological Characteristics and Internationalisation in INVs}

INVs are able to attain profitable global positions by acquiring a competitive advantage through innovation. This innovation can be copied by competitors, so INVs may prevent this by various means such as patents or licences. Suggesting a patent or an international certificate as a measure of the standardisation of technology, Bloodgood et al. [28] showed that firms with higher technological intensities could have a higher level of internationalisation and higher market share. Investigating the rapid internationalisation processes of high-technology companies, McGuinness and Little [29] and Sleuwaegen and Onkelinx [4] suggested that because companies have to spend higher research and development (R\&D) costs and have shorter product life cycles, they would like to expand into new global markets rather than domestic markets with limited demand. In this environment, patents and international and domestic certificates can be considered significant determinants of internationalisation.

The level of technological innovation plays a pivotal role in promoting internationalisation of INVs [30]. Carrying out empirical research, Madsen [31] argued that a higher level of technological standardisation and innovation could function as antecedents of rapid internationalisation. Drawing on similar results, Tyebjee [32] also suggested that there are significant relationships between technological characteristics and internationalisation of INVs. Meanwhile, Shrader [33] emphasised that INVs are not only identifying innovative and differentiated products as sources of competitive advantage but also pursuing these advantages throughout technological innovation. According to Shrader's argument, INVs aspire to the rapid internationalisation for offsetting the cost of generating their R\&D capacities; in other words, technological capacities such as R\&D capacities can determine internationalisation. Because INVs in high-technology industries tend to focus on specialised niche markets with limited numbers of customers, they can be threatened by insufficient demand if they focus on the domestic market alone [17,30]. Therefore, INVs with stronger technological capacities would like to enter into a new global market. Burgel and Murray [9] and Tanev [34] also emphasised that technological innovation and capability may promote improved international performance. Finally, considering the environment and the context of high-technology industry, Lee and Park [23] suggested five technological characteristics such as intelligent technology (IT) application capacity, technological capability, technological imitation, technological innovativeness, and technological standards. However, all INVs do not utilise IT, so this study would like to consider four technological 
characteristics based on Lee and Park [23]. Based on the above literature, this study would like to test the following hypothesis.

Hypothesis 1. The Technological Characteristics of INVs Have Significant Effects on Internationalisation.

\subsection{Relationships among Technological Characteristics, CEOs' Global Orientation, and Internationalisation}

From the perspective of resource-based theory, human resources are a critical factor determining organisational competitiveness; this fact can apply to INVs. Researchers [28,35] who study the characteristics of INVs and their internationalisation processes have argued that human resources play an important role in determining when INVs will find a new market abroad. Moreover, they suggested that there are significant correlations between the rapid internationalisation and the characteristics of the CEOs and founders in INVs [13]. In the case of INVs established under CEOs' global experience and orientation, and management expertise, CEOs or founders play an essential role in determining whether to enter foreign markets as soon as the foundation of INVs [36]. The pace of internationalisation tends to depend on the CEOs' global orientation [37,38]. Even though customers' awareness about INVs and their products may be low, their awareness about CEOs of them could be relatively high. Moreover, technological characteristics of INVs such as the level of technological innovation and capability can be affected by the top management's level of technological expertise. CEOs' global orientation and technological background, therefore, have positive (+) effects on internationalisation [37,39]. Kuemmerle [40] and Sala and Yalcin [41] have also suggested that a significant relationship exists between entrepreneurial characteristics such as global orientation and the speed or level of internationalisation. This association is due to CEOs' abilities to be able to reduce the cultural and psychological barriers, and we would like to define these abilities as global orientation. Reuber and Fischer [42] found that top management's knowledge and experience could function as the determinants of rapid internationalisation. In a similar vein, Johanson and Mattsson [43] emphasised that CEOs' or founders' global orientation could positively affect the internationalisation, that is, when a CEO has stronger global orientation, the level of internationalisation will be higher. Those authors also found that these entrepreneurial characteristics could improve the level of internationalisation by facilitating interactions with the external environment.

In a study on the internationalisation based on 311 high-technology companies in the United Kingdom, Burgel and Murray [9] concluded that entrepreneurs' global experience and orientation were critical features of INVs. Sala and Yalcin [41] also argued that entrepreneurs' global orientation were able to determine the level and pattern of internationalisation of INVs. Furthermore, in a study of 335 SMEs in Norway, Moen [24] found a significant relationship between CEOs' global orientation and the pace of internationalisation. In other words, global orientation has acted as an important factor determining the internationalisation of INVs. Studies focusing on management strategies [24,44] have indicated that entrepreneurial characteristics such as global orientation play a pivotal role in improving international performance. These studies reflect the dependence of INVs on CEOs' experience and ability to overcome the difficulties associated with reductions in demand and profits. In other words, the CEO's global orientation is an important variable that can affect the internationalisation and performance of INVs [24]. Considering a network with the external environment as an antecedent of internationalisation, scholars [45] have argued that to cope with insufficient resources and low visibility, INVs must depend on their CEOs' global experience and orientation, and technological capabilities. Manolova et al. [13] indicated that, for INVs, the CEOs' global orientation is critical to improving the international performance. In a study of 75 high-technology firms in Ontario, Preece et al. [46] also concluded that entrepreneurs' international experience and global orientation determine their companies' internationalisation pattern. In addition, Harvestion [47] empirically demonstrated that entrepreneurs' global orientation could help their firms internationalise more quickly and successfully than their competitors. Finally, Barbat et al. [37] and Kuemmerle [40] revealed that the global orientation and experience of top management are important variables 
that help to distinguish INVs from other similar companies. The above studies led us to propose the following hypotheses.

Hypothesis 2. Global Orientation Has a Positive Effect on Internationalisation.

Hypothesis 3. Global Orientation Mediates the Relationships between Technological Characteristics and Internationalisation.

Based on the prior studies, this study would like to propose the conceptual model shown in Figure 1.

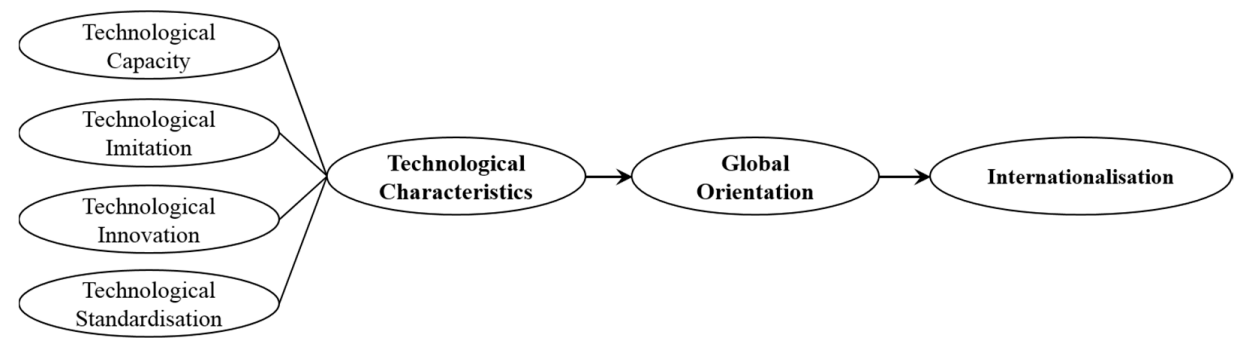

Figure 1. Research model.

\section{Methodology}

\subsection{Operational Definition of INVs}

Because there is no official database on INVs in South Korea, it is difficult to accurately classify. Therefore, the more exact estimate on the pace of internationalisation among INVs could be achieved by cross-checking the information such as the time since foundation and the duration of export activity in the websites of the respondents against the data provided by a reliable government agency, the Korea Venture Business Association. In this context, this study defined INVs as "companies that find markets abroad less than six years after their foundation" based on prior literature [12,22].

\subsection{Sample and Data Collection}

This study is based on INVs that penetrated international markets within six years after foundation. Because there are no official data that can identify INVs, this study used multiple sources such as websites to choose research samples [48]. Various database sources such as the Korea Venture Business Association, INNO-BIZ, and the Korea International Trade Association were used to select the appropriate INVs. The details of the sampling procedure are described as follows. First, the Korea Venture Business Association provided data regarding firms conducting business internationally. Based on these data, we identified 1279 ventures suitable for this study. Second, we visited the websites for individual firms on INNO-BIZ, a government agency for technology-intensive SMEs (many of which might be expected to be INVs), and discovered an additional 212 ventures appropriate for our research purposes. Third, we analysed data from the Korean International Trade Association concerning more exact export times and identified 589 INVs among these 1491 ventures. Finally, in order to improve the reliability and validity of our sampling procedure, we again visited the websites of INVs identified above to confirm their suitability for this study before the survey. As a result, 517 of the 589 INVs were chosen. Because most INVs are high-technology firms, an online survey is an ideal way to collect data from them. However, to improve the survey response rate, we implemented an offline survey along with the online version [49]. Specifically, we distributed 517 offline questionnaires to the INVs identified by the above processes in December 2014. After one month, we sent online questionnaires to the INVs. Subsequently, we sent the INVs two emails (separated by a one month interval) asking them to participate in our survey. In an additional effort to improve the response rate, we contacted the CEOs or directors in person. Moreover, we distributed 100 questionnaires to other INVs in December 2015. 
Consequently, we collected 378 questionnaires (collection rate: 61.3\%). Among these questionnaires, 20 could not be used because they had not been completely answered. Ultimately, 358 questionnaires were employed. As a result of investigating the demographics and key characteristics of the sample, including the respondents' gender and position, the number of employees, the amount of time since being founded, and the duration of export activity. In particular, most of the respondents have higher positions than the general manager. For instance, the respondents are composed of CEOs $(12.5 \%$; 45 respondents), senior managers (29.4\%; 105 respondents), general managers ( $40.6 \%$; 145 respondents), and staff (17.5\%; 63 respondents). Even though more than half of respondents have higher positions than the general manager, they can represent CEO intention as they play a pivotal role in making important decisions with CEOs. Finally, all of the respondents penetrated into international markets within six years after foundation.

\subsection{Measures}

\subsubsection{Technological Characteristics}

The results of previous studies suggest that technological characteristics constitute one of the most important determinants of internationalisation. Based on previous literature [23,50], four types of technological characteristics were analysed in this study: technological capacity, technological imitation, technological innovation, and technological standardisation. We defined these factors as follows: technological capacity is the ability to produce and provide innovative, leading, and distinguished goods and services while covering R\&D costs; technological imitation is the extent to which a firm's output can be imitated or copied by competitors; technological innovation is how rapidly an INV is able to produce new or innovative goods and services; and technological standardisation is the possession of domestic and international certificates and the means by which an INV standardises its technology. To assess these variables, five, four, four, and five items, respectively, were measured using a five-point Likert-type scale ( $1=$ strongly disagree; $5=$ strongly agree). The detailed items are explained in Appendix A.

\subsubsection{Global Orientation}

The entrepreneurial characteristic evaluated in this study was the CEOs' global orientation. Based on Oviatt and McDougall [51] and Zucchella [20], we defined global orientation as the intention to pursue new international markets. Furthermore, we defined international business experience as the ability to discover useful information about the targeted international markets and the frequency of overseas trips. The CEOs' global orientation was measured using four indicators. All of the indicators were measured using a five-point Likert-type scale ( 1 = strongly disagree; $5=$ strongly agree). The detailed measurements are explained in Appendix A.

\subsubsection{Internationalisation}

Four items were used to measure internationalisation: export sales, international assets, number of international markets, and number of international branches. All of these items were derived from studies by Bloodgood [52] and Kuivalainen [53] and were measured using a five-point Likert-type scale $(1=$ strongly disagree; 5 = strongly agree). The detailed items are explained in Appendix A.

\subsubsection{Assessing Common Method Bias and Non-Response Bias}

In spite of the fact that we collected questionnaires at regular intervals to minimise common method bias, it is very difficult to avoid this type of bias perfectly [54]. Therefore, we performed a confirmatory factor analysis (CFA) to assess the likelihood of common method bias. The results were as follows: $\chi^{2}=1978.357$ ( $\mathrm{df}($ degree of freedom) $=309, p=0.000), \chi^{2} / \mathrm{df}=6.402$, the Goodness of Fit Index $(\mathrm{GFI})=0.627$, the Adjusted Goodness of Fit Index $(\mathrm{AGFI})=0.594$, the Root Mean square Residual $(\mathrm{RMR})=0.219$, and the Root Mean Square Error of Approximation (RMSEA) $=0.148$. These 
results indicate a lack of statistical significance, i.e., an extremely poor model fit. Therefore, we can conclude that the study was unlikely to be affected by common method bias.

Meanwhile, in order to measure the likelihood of non-response bias, this study used a $t$-test suggested by Armstrong and Overton [55]. We compared the early responses (within one month of the mailing) with the late responses (more than one month after the mailing) in terms of key variables such as global orientation, internationalisation, and technological characteristics. As a result, we could not find any significant differences between the two groups. Therefore, we can conclude that there is non-response bias in this study.

\section{Analysis and Results}

\subsection{Measurement Model Results}

Throughout structural equation modelling (SEM), this study investigated the relationships among technological characteristics, global orientation, and internationalisation. Before testing the hypotheses utilising the structural model, this study assessed the measurement model, which was created to assess the reliability and validity of the constructs used in this study. The confirmatory factor analysis (CFA) was used to evaluate the measurement model, which was composed of six constructs by IBM AMOS 21.0 (New York, NY, USA). In order to test, we put every construct (i.e., technological characteristics, global orientation, and internationalisation) into the measurement model, and hence verified the reliability and the validity of the measurement model by utilising the CFA. As a result of testing the measurement model, although the chi-squared $\left(\chi^{2}\right)$ value did not show satisfactory statistical significance $\left(\chi^{2}=830.283, \mathrm{df}=309, \chi^{2} / \mathrm{df}=2.687\right.$; Table 1$)$, it tends to be biased against large samples $[56,57]$. For overcoming this limitation, we verified the overall fit of the measurement model by using several other indices. The results are as follows: the GFI is 0.921; the AGFI is 0.902; the Comparative Fit Index (CFI) is 0.943; the Normed Fit Index (NFI) = 0.919; the Tucker-Lewis Index $(\mathrm{TLI})=0.922$; the RMR is 0.051 ; the RMSEA is 0.055 . Based on the thresholds, the overall fit of the measurement model was satisfactory. Cronbach's alpha $(\alpha)$ was employed to assess the reliability of all of the constructs used. The Cronbach's $\alpha$ values of all of the constructs in this study ranged from 0.812 to 0.952 , as well as the construct reliability of each scale ranged from 0.852 to 0.968 [58]. Thus, there is no problem on the reliability. As shown in Table 1, we calculated the average variance extracted (AVE) in order to estimate the convergent validity of all the constructs. Because all of the AVE values were greater than 0.512 , we can conclude that this measurement model had satisfactory convergent validity [59].

Table 1. Measurement model results.

\begin{tabular}{|c|c|c|c|c|c|c|c|c|}
\hline \multirow[t]{2}{*}{ Scale } & \multirow[t]{2}{*}{ Mean } & \multirow[t]{2}{*}{ S.D. } & \multicolumn{6}{|c|}{ Cross-Construct Correlations } \\
\hline & & & (1) & (2) & (3) & (4) & (5) & (6) \\
\hline (1) & 2.3006 & 0.99317 & 1 & & & & & \\
\hline (2) & 2.6648 & 0.91214 & $0.309^{* *}$ & 1 & & & & \\
\hline (3) & 3.3052 & 0.91033 & $0.444^{* *}$ & $0.404^{* *}$ & 1 & & & \\
\hline (4) & 2.3911 & 0.89275 & $0.640^{* *}$ & $0.504^{* *}$ & $0.419 * *$ & 1 & & \\
\hline (5) & 3.1475 & 1.05869 & $0.508^{* *}$ & $0.227^{* *}$ & $0.276^{* *}$ & $0.402 * *$ & 1 & \\
\hline (6) & 2.4588 & 0.95827 & $0.646^{* *}$ & $0.295^{* *}$ & $0.371^{* *}$ & $0.575^{* *}$ & $0.421^{* *}$ & 1 \\
\hline \multicolumn{3}{|c|}{ Cronbach's $\alpha$} & 0.874 & 0.812 & 0.872 & 0.905 & 0.952 & 0.918 \\
\hline \multicolumn{3}{|c|}{ Construct Reliability } & 0.852 & 0.807 & 0.881 & 0.968 & 0.910 & 0.930 \\
\hline \multicolumn{3}{|c|}{ AVE } & 0.596 & 0.512 & 0.598 & 0.858 & 0.719 & 0.729 \\
\hline \multicolumn{3}{|c|}{ Goodness-of-fit statistics } & $\begin{array}{r}\chi^{2}= \\
\text { AGFI }\end{array}$ & $2, N F$ & $\begin{array}{l}, \chi^{2} / d \\
19, \text { CFI }\end{array}$ & $\begin{array}{l}87 \text {, RM } \\
\text { 43, TLI }\end{array}$ & $\begin{array}{l}0.051, \mathrm{G} \\
22, \mathrm{RM}\end{array}$ & $\begin{array}{l}921, \\
0.055\end{array}$ \\
\hline
\end{tabular}

* Significant at $p<0.01 .{ }^{* *}$ Significant at $p<0.05$. (1) Technological Capacity; (2) Technological Imitation; (3) Technological Innovation; (4) Technological Standardisation; (5) Global Orientation; (6) International Performance. $\mathrm{df}=$ degree of freedom; RMR = Root Mean square Residual; GFI = Goodness Fit Index; AGFI = Adjusted Goodness of Fit Index; NFI = Normed Fit Index; CFI = Comparative Fit Index; TLI = Tucker-Lewis Index; RMSEA = Root Mean Square Error of Approximation . 


\subsection{Structural Model Results}

As a result of exploring the model fits, the $\chi^{2}$ value is 847.241. Therefore, we examined other indices. The values of these indices (GFI $=0.921, \mathrm{AGFI}=0.901, \mathrm{CFI}=0.943, \mathrm{NFI}=0.918, \mathrm{TLI}=0.922$, RMR $=0.051$, and RMSEA $=0.053$ ) met the thresholds considered to indicate the satisfactory model fits.

\subsection{Hypotheses Testing}

\subsubsection{Hypotheses 1 and 2}

We tested the research hypotheses by examining disintegration effects. The hypotheses were assessed by interpreting the path coefficients. First of all, we could determine that these direct effects could predict significant relationships between technological characteristics and internationalisation. All of the examined technological characteristics such as technological capacity, imitation, innovation, and standardisation had significant effects on internationalisation. Specifically, technological capacity $(\lambda=0.297, C . R=4.122, p<0.001)$, technological innovation $(\lambda=0.239, C . R=4.819, p<0.001)$, and technological standardisation $(\lambda=0.147, C . R=2.133, p<0.05)$ had significant positive (+) effects on internationalisation, whereas technological imitation $(\lambda=-0.199, \mathrm{C} . \mathrm{R}=-2.000, p<0.05)$ had a significant negative (-) effect on internationalisation. These results indicate that INVs with the higher levels of technological capacity, innovation, and standardisation and lower susceptibility to technological imitation tend to penetrate into new international markets successfully. Our findings demonstrate that technological characteristics are one of the most important determinants of successful internationalisation. In summary, hypothesis 1 was supported.

In order to verify the mediating effects of the CEO's global orientation, we evaluated the relationships between independent variables and a mediating variable [60]. As shown in Tables 1 and 2, significant correlations were observed between the CEO's global orientation and the technological characteristics (correlation with technological capacity was 0.508 ; with technological imitation was 0.227; with technological innovation was 0.276 ; and with technological standardisation was 0.402 ) as well as internationalisation of INVs. Therefore, hypothesis 2 was supported and the prerequisite was satisfied (i.e., significant correlations exist between the technological characteristics and the global orientation).

Table 2. Standardised structural estimates of the structural model.

\begin{tabular}{|c|c|c|c|}
\hline Path & Estimate & C.R $*$ & $p$-Value \\
\hline \multicolumn{4}{|l|}{ Direct Effects } \\
\hline Technological Capacity $\rightarrow$ Internationalisation & 0.297 & 4.122 & 0.000 \\
\hline Technological Imitation $\rightarrow$ Internationalisation & -0.199 & -2.000 & 0.043 \\
\hline Technological Innovation $\rightarrow$ Internationalisation & 0.239 & 4.819 & 0.000 \\
\hline Technological Standardisation $\rightarrow$ Internationalisation & 0.147 & 2.133 & 0.033 \\
\hline Technological Capacity $\rightarrow$ Global orientation & 0.215 & 2.385 & 0.017 \\
\hline Technological Imitation $\rightarrow$ Global orientation & -0.117 & -1.989 & 0.048 \\
\hline Technological Innovation $\rightarrow$ Global orientation & 0.425 & 4.662 & 0.000 \\
\hline Technological Standardisation $\rightarrow$ Global orientation & 0.318 & 4.886 & 0.000 \\
\hline Global orientation $\rightarrow$ Internationalisation & 0.505 & 9.385 & 0.000 \\
\hline \multicolumn{4}{|l|}{ Indirect Effects } \\
\hline Technological Capacity $\rightarrow$ Global orientation $\rightarrow$ Internationalisation & 0.122 & & 0.035 \\
\hline Technological Imitation $\rightarrow$ Global orientation $\rightarrow$ Internationalisation & 0.146 & & 0.027 \\
\hline Technological Innovation $\rightarrow$ Global orientation $\rightarrow$ Internationalisation & 0.176 & & 0.010 \\
\hline Technological Standardisation $\rightarrow$ Global orientation $\rightarrow$ Internationalisation & 0.232 & & 0.010 \\
\hline \multicolumn{4}{|c|}{$\begin{array}{l}\text { Goodness-of-fit statistics } \\
\chi^{2}=847.241(\mathrm{df}=309) ; \chi^{2} / \mathrm{df}=2.742 ; \mathrm{RMR}=0.051 ; \mathrm{GFI}=0.921 ; \mathrm{AGFI}=0.901 ; \\
\mathrm{NFI}=0.918 ; \mathrm{CFI}=0.943 ; \mathrm{TLI}=0.922 ; \mathrm{RMSEA}=0.053\end{array}$} \\
\hline
\end{tabular}




\subsubsection{Hypothesis 3}

One of the research purposes is to investigate the mediating effects of the CEO's global orientation on the relationships between technological characteristics and internationalisation. For assessing the mediating role of CEOs' global orientation, we analysed indirect effects suggested by Baron and Kenny [60]. A significant indirect effect demonstrates that a significant portion of the independent variable's total effect on the dependent variable occurs throughout the mediator. Consequently, we could confirm that the CEO's global orientation mediated the relationships between technological characteristics (i.e., technological capacity, imitation, innovation, and standardisation) and internationalisation. Judging from the statistics, we could identify that technological capacity, technological innovation, and technological standardisation had significant positive (+) effects on internationalisation, while technological imitation had a significant negative $(-)$ effect on that. Testing the second process, we concluded that technological capacity $(\lambda=0.215, C . R=2.385, p<0.05)$, technological innovation $(\lambda=0.425, C . R=4.662, p<0.001)$, and technological standardisation $(\lambda=0.318$, $C . R=4.886, p<0.01)$ influenced the global orientation positively, whereas technological imitation $(\lambda=-0.117, C . R=-1.989, p<0.05)$ influenced this negatively. Finally, by assessing the indirect effects of the hypothesised paths, we estimated whether to be the mediating role of global orientation. As a result, we could conclude that the CEO's global orientation mediated the successful internationalisation by improving technological capacity $(\lambda=0.122, p=0.035)$, imitation $(\lambda=0.146, p=0.027)$, innovation $(\lambda=0.176, p=0.010)$, and standardisation $(\lambda=0.232, p=0.010)$. These results suggest that the CEO's global orientation can mediate the relationships between these technological characteristics and internationalisation of INVs. Furthermore, our findings suggest that the CEO's global orientation plays a pivotal role in carrying out the successful internationalisation, and converting advantageous technological characteristics of the INV into successful internationalisation. In particular, it implies that even though INVs have superior technological competence compared to other rivals, they cannot enter into global markets if CEOs do not have the intentions to penetrate into new global markets. Based on the above results, hypothesis 3 was also supported.

\section{Conclusions}

\subsection{Summary and Implications}

With the goal of helping INVs improve their international performance, this study developed a conceptual model considering the technological characteristics of the INVs (i.e., technological capacity, imitation, innovation, and standardisation) and the CEO's global orientation as major variables affecting successful internationalisation. For achieving this goal, several hypotheses were made and hence tested empirically. The findings are as follows. First, the technological characteristics of INVs have significant effects on their internationalisation. Second, there are significant correlations between the technological characteristics of INVs and the CEO's global orientation, as well as between the CEO's global orientation and the internationalisation. Finally, the CEO's global orientation partially mediates the relationships between the technological characteristics and the internationalisation of INVs.

These results imply that CEOs in INVs should pay more attention to the technological characteristics to improve their international performance. More specifically, our findings emphasise that INVs can be more likely to improve their international performance when they have or manage a greater of technological capacity, innovation, standardisation, and imitation. Considering technological characteristics, most of the studies [34,61] utilised one or two characteristics such as technological capacity or technological innovation. As far as we know, there should be no comprehensive study. Therefore, this study has a significant implication that proposes a research direction that various technological characteristics can affect internationalisation, and these characteristics should be studied more comprehensively. In the case of SMEs like INVs, it is very difficult to internationalise due to limited resources [62]. Thus, nothing is more important than CEOs' choices to enter into new international markets. That is to say, this study suggests that the CEO's global orientation 
plays an important role in promoting rapid internationalisation [62]. Finally, it implies that in export-oriented countries such as South Korea, successful internationalisation is needed to have national competitiveness, suggesting that investigating the characteristics of INVs, that have played an essential role in improving the competitiveness, is significant and meaningful for both academia and industry that would like to carry out the successful internationalisation. In South Korea, research on INVs is relatively new but very interesting. For instance, Lee et al. [63] conducted several case studies of INVs in South Korea. They have studied the pace and processes of internationalisation among Korean venture companies that seek to expand overseas. However, aside from these studies, relatively little empirical research has been devoted to INVs in South Korea. Therefore, the empirical research is quite significant.

\subsection{Limitations and Future Research Directions}

There are some limitations in this study. First of all, this study relied heavily on just quantitative methods such as surveys. This approach is inadequate for considering individuals' in-depth opinions. Therefore, future research utilising both qualitative and quantitative measures needs to be carried out. Second, this study has some academic limitations. Actually, this study considered restricted factors on internationalisation, so it is necessary to evaluate other variables such as environmental factors (e.g., regulations or support policies) that might be significantly associated with internationalisation hereafter. Third, this study designated CEOs' global orientation as a mediating variable; however, the global orientation can function as a moderating variable. Consequently, future studies need to consider the moderating role of CEO's global orientation in improving internationalisation. Finally, due to the fact that this study was focused on INVs in South Korea, it is difficult to generalise the above results. Therefore, a comparative study between two or more countries such as China or export-depended countries (e.g., Finland, Germany and so on) needs to be carried out for increasing the ability to generalise the results.

Acknowledgments: This work (Grants No. 10016911) was supported by Business for University Entrepreneurship Center, funded Korea Small and Medium Business Administration in 2014.

Author Contributions: Junghyun Yoon (The first author) is a research assistant professor in POSTECH Entrepreneurship Centre, South Korea. As the first author, he designed the research conceptual model, collected the survey data, and interpreted the survey results. Dae-su Kim (Corresponding author) is a lecturer in Yeungnam University, South Korea. He had acted as a corresponding author who analysed the survey data and hence interpreted the analysed results with Junghyun Yoon.

Conflicts of Interest: The authors declare no conflict of interest.

\section{Appendix A}

Table A1. Measurement Items (Questionnaire).

\begin{tabular}{|c|c|}
\hline Variables & Items \\
\hline $\begin{array}{l}\text { Technological } \\
\text { Capacity }\end{array}$ & $\begin{array}{l}\text { My organisation leads the technology trend. } \\
\text { My organisation develops necessary technologies effectively. } \\
\text { My organisation has a capacity to be able to supply more innovative products than rivals. } \\
\text { My organisation has a technological ascendancy over rivals. }\end{array}$ \\
\hline $\begin{array}{l}\text { Technological } \\
\text { Imitation }\end{array}$ & $\begin{array}{l}\text { The technology of my organisation can be used universally. } \\
\text { The technology of my organisation can be learned by observation. } \\
\text { The technology of my organisation can be imitated more easily. } \\
\text { The technology of my organisation can be learned more easily. }\end{array}$ \\
\hline $\begin{array}{l}\text { Technological } \\
\text { Innovation }\end{array}$ & $\begin{array}{l}\text { The extent of technological innovation is higher than rivals. } \\
\text { The CEO of my organisation thinks that technological innovation is an important thing. } \\
\text { My organisation can acquire useful information needed to carry out successful } \\
\text { technological innovation. } \\
\text { My organisation has a culture or environment needed to carry out successful } \\
\text { technological innovation. }\end{array}$ \\
\hline
\end{tabular}


Table A1. Cont.

\begin{tabular}{ll}
\hline Variables & Items \\
\hline \multirow{3}{*}{$\begin{array}{l}\text { Technological } \\
\text { Standardisation }\end{array}$} & $\begin{array}{l}\text { My organisation has more international certificates such as ISOs than rivals. } \\
\text { My organisation has more internal or domestic certificates than rivals. } \\
\text { The CEO of my organisation supports technological standardisation. }\end{array}$ \\
\hline & The CEO of my organisation has enough international experience. \\
& The CEO of my organisation has carried out sufficient international business. \\
Global Orientation & The CEO of my organisation can speak foreign language such as English fluently. \\
& The CEO of my organisation has an intention to internationalise. \\
& The CEO of my organisation is interesting in penetrating into new international markets. \\
\hline \multirow{3}{*}{ Internationalisation } & International sales \\
& International assets \\
& The number of international branches \\
& The number of international markets or countries penetrated \\
\hline
\end{tabular}

\section{References}

1. Cerrato, D.; Piva, M. The effect of global orientation on the performance of international new ventures: Evidence from Italy. Manag. Int. Rev. 2015, 55, 857-883. [CrossRef]

2. Johanson, J.; Vahlne, J.E. The internationalisation process of the firm-A model of knowledge development and increasing foreign market commitment. J. Int. Bus. Stud. 1977, 8, 23-32. [CrossRef]

3. Cavusgil, S.T.; Knight, G. The born global firm: An entrepreneurial and capabilities perspective on early and rapid internationalization. J. Int. Bus. Stud. 2015, 46, 3-16. [CrossRef]

4. Sleuwaegen, L.; Onkelinx, J. International commitment, post-entry growth and survival of international new ventures. J. Bus. Ventur. 2014, 29, 106-120. [CrossRef]

5. Oviatt, B.M.; McDougall, P.P. Challenges for internationalisation process theory: The case of international new ventures. Manag. Int. Rev. 1997, 37, 85-99.

6. McDougall, P.; Shane, S.; Oviatt, B.M. Explaining the formation of international new ventures. J. Bus. Ventur. 1994, 9, 469-487. [CrossRef]

7. Cavusgil, S.T. On the internationalisation process of firms. Eur. Res. 1980, 8, 273-281.

8. Moen, O.; Servais, P. Born global or gradual global? Examining the export behavior of small and medium-sized enterprises. J. Int. Mark. 2002, 10, 49-72. [CrossRef]

9. Burgel, O.; Murray, G.C. The international market entry choices of start-up companies in high technology industries. J. Int. Mark. 2000, 8, 33-62. [CrossRef]

10. Chorev, S.; Anderson, A.R. Success in Israeli high-tech start-ups; Critical factors and process. Technovation 2006, 26, 162-174. [CrossRef]

11. Rialp, A.; Rialp, J.; Knight, G.A. The phenomenon of early internationalizing firms: What do we know after a decade (1993-2003) of scientific enquiry? Int. Bus. Rev. 2005, 14, 147-166. [CrossRef]

12. McDougall, P.P.; Oviatt, B.M.; Shrader, R.C. A comparison of international and domestic new ventures. J. Int. Entrep. 2003, 1, 59-82. [CrossRef]

13. Manolova, T.S.; Brush, C.G.; Edelman, L.F.; Greene, P.G. Internationalization of small firms: Personal factors revisited. Int. Small Bus. J. 2002, 20, 9-31. [CrossRef]

14. Ruzzier, M.; Antoncic, B.; Hisrich, R.D.; Konecnik, M. Human capital and SME internationalization: A structural equation modeling study. Can. J. Adm. Sci. 2007, 24, 15-29. [CrossRef]

15. Knight, G.A.; Cavusgil, S.T. A taxonomy of born-global firms. Manag. Int. Rev. 2005, 45, 15-35.

16. Fernhaber, S.A.; Gilbert, B.A.; McDougall, P.P. International entrepreneurship and geographic location: An empirical examination of new venture internationalization. J. Int. Bus. Stud. 2008, 39, 267-290. [CrossRef]

17. Oviatt, B.M.; McDougall, P.P. Global start-ups: Entrepreneurs on a worldwide stage. Acad. Manag. Exec. 1994, 9, 30-43. [CrossRef]

18. Madsen, T.K.; Servais, P. The internationalization of born globals: An evolutionary process? Int. Bus. Rev. 1997, 6, 561-583. [CrossRef]

19. Acedo, F.; Jones, M.V. Speed of internationalization and entrepreneurial cognition: Insights and a comparison between international new ventures, exporters and domestic firms. J. World Bus. 2007, 42, 236-252. [CrossRef] 
20. Zucchella, A.; Danicolia, S.; Palamara, G. The drivers of the early internationalization of the firm. J. World Bus. 2007, 42, 268-280. [CrossRef]

21. Knight, G.A.; Cavusgil, T.S. The Born Global Firm: A Challenge to Traditional Internationalization Theory. In Export Internationalizing Research-Enrichment and Challenges. Advances in International Marketing; Cavusgil, S.T., Madsen, T.K., Eds.; JAI Press: New York, NY, USA, 1996; Volume 8, pp. 11-26.

22. Rhee, J.; Park, T. Born global: Effects of international orientation and network on international intensity. Korean Ventur. Manag. Rev. 2009, 12, 1-26.

23. Lee, H.Y.; Park, G.S. An empirical study on technology characteristics and international performance in born-globals in accordance with CEOs' international experience. J. Int. Trade Commer. 2013, 9, 237-261. [CrossRef]

24. Moen, O. The born globals: A new generation of small European exporters. Int. Mark. Rev. 2002, 19, $156-175$. [CrossRef]

25. Sharma, D.D.; Blomstermo, D. The internationalization process of born globals: A network view. Int. Bus. Rev. 2003, 12, 739-753. [CrossRef]

26. Chetty, S.K.; Campbell-Hunt, C. A strategic approach to internationalisation: A traditional versus a born-global approach. J. Int. Mark. 2004, 12, 57-81. [CrossRef]

27. Bailetti, T. Technology entrepreneurship: Overview, definition, and distinctive aspects. Technol. Innov. Manag. Rev. 2012, 2, 5.

28. Bloodgood, J.M.; Sapienza, H.J.; Almeida, J.G. The internationalization of new high-potential U.S. ventures: Antecedents and outcomes. Entrep. Theory Pract. 1996, 20, 61-76.

29. McGuinness, N.W.; Little, B. The impact of R\&D spending on the foreign sales of new Canadian industrial products. Res. Policy 1991, 10, 78-98.

30. Onetti, A.; Zucchella, A.; Jones, M.V.; McDougall-Covin, P.P. Internationalization, innovation and entrepreneurship: Business models for new technology-based firms. J. Manag. Gov. 2012, 16, 337-368. [CrossRef]

31. Madsen, T.K. Early and rapidly internationalizing ventures: Similarities and differences between classifications based on the original international new venture and born global literatures. J. Int. Entrep. 2013, 11, 65-79. [CrossRef]

32. Tyebjee, T.T. Internationalization of high-tech firms: Initial vs. extended involvement. J. Glob. Mark. 1995, 7, 59-81. [CrossRef]

33. Shrader, R.C. Collaboration and performance in foreign markets: The case of young high-technology manufacturing firms. Acad. Manag. J. 2001, 44, 45-60. [CrossRef]

34. Tanev, S. Global from the start: The characteristics of born-global firms in the technology sector. Technol. Innov. Manag. Rev. 2012, 2, 5.

35. Gabrielsson, M.; Gabrielsson, P.; Dimitratos, P. International entrepreneurial culture and growth of international new ventures. Manag. Int. Rev. 2014, 54, 445-471. [CrossRef]

36. Kandasaami, S.; Huang, X. International Marketing Strategy of SMEs: A Comparison of Born-Global vs. Non Born-Global Firms in Australia. In Proceedings of the ICSB Conference, Brisbane, Australia, 7-10 June 2000.

37. Barbat, V.; Hlady Rispal, M.; Randerson, K. Disentangling the roles of international entrepreneurial orientation and networking in the internationalisation process of SESBs. Int. J. Entrep. Small Bus. 2014, 23, 363-384. [CrossRef]

38. Zahra, S.A.; George, G. International Entrepreneurship: The Current Status of the Field and Future Research Agenda. In Strategic Entrepreneurship: Creating a New Mind-Set; Hitt, M., Ireland, D., Sexton, D., Camp, M., Eds.; Blackwell Publishers: Oxford, UK, 2002; pp. 255-288.

39. Rasmussen, E.; Madsen, T.K.; Evangelista, F. The founding of the Born Global Company in Denmark and Australia: Sense-making and networking. Asia Pac. J. Mark. Logist. 2001, 13, 75-107. [CrossRef]

40. Kuemmerle, W. Home base and knowledge management in international new ventures. J. Bus. Ventur. 2002, 17, 99-122. [CrossRef]

41. Sala, D.; Yalcin, E. Export experience of managers and the internationalisation of firms. World Econ. 2015, 38, 1064-1089. [CrossRef]

42. Reuber, R.A.; Fischer, E. The influence of top management team's international experience on the internationalization behaviors of SMEs. J. Int. Bus. Stud. 1997, 28, 807-825. [CrossRef] 
43. Johanson, J.; Mattsson, L. Internationalization in Industrial Systems: A Network Approach. In Strategies for Global Competition; Hood, N., Ed.; Croom Helm: London, UK, 1988; pp. 287-314.

44. Melén Hånell, S.; Rovira Nordman, E.; Deo Sharma, D. The continued internationalisation of an international new venture. Eur. Bus. Rev. 2014, 26, 471-490. [CrossRef]

45. Luostarinen, R.; Gabrielsson, M. Finnish Perspectives of International Entrepreneurship. In Handbook of Research on International Entrepreneurship; Dana, L.P., Ed.; Edward Elgar: Cheltenham, UK, 2004; pp. $383-403$.

46. Preece, S.B.; Miles, G.; Baetz, M.C. Explaining the international intensity and global diversity of early-stage technology-based firms. J. Bus. Ventur. 1998, 14, 259-281. [CrossRef]

47. Harvestion, P.D. Synoptic Versus Incremental Internationalization: An Examination of 'Born Global' and 'Gradual Globalizing' Firms. Unpublished Thesis, University of Memphis, Memphis, TN, USA, 2000.

48. Nummela, N.; Saarenketo, S.; Puumalainen, K. Global mindset-A prerequisite for successful internationalization? Can. J. Adm. Sci. 2004, 21, 51-64. [CrossRef]

49. Kaplowitz, M.C.; Hadlock, T.D.; Levine, R. A comparison of web and mail survey response rates. Public Opin. Q. 2004, 68, 94-101. [CrossRef]

50. Zahra, S.A.; Korri, J.S.; Yu, J. Cognition and international entrepreneurship: Implications for research on international opportunity recognition and exploitation. Int. Bus. Rev. 2005, 14, 129-146. [CrossRef]

51. Oviatt, B.M.; McDougall, P.P. A Framework for Understanding Accelerated International Entrepreneurship. In Research in Global Strategic Management: International Entrepreneurship; Rugman, A.M., Wright, R.W., Eds.; JAI Press: Stamford, CT, USA, 1999; pp. 23-40.

52. Bloodgood, J.M. Venture adolescence: Internationalization and performance Implications of Maturation. Int. J. Entrep. Behav. Res. 2006, 12, 67-84. [CrossRef]

53. Kuivalainen, D.; Sundqvist, S.; Servais, P. Firms' degree of born-globalness, international entrepreneurial orientation and export performance. J. World Bus. 2007, 42, 253-267. [CrossRef]

54. Podsakoff, P.M.; Organ, D.W. Self-reports in organizational research: Problems and prospects. J. Manag. 1986, 12, 531-544. [CrossRef]

55. Armstrong, J.S.; Overton, T.S. Estimating nonresponse bias in mail surveys. J. Mark. Res. 1997, 14, $396-402$. [CrossRef]

56. Bagozzi, R.P.; Baumgartner, H. The Evaluation of Structural Equation Models and Hypothesis Testing. In Principles of Marketing Research; Bagozzi, R., Ed.; Mass Blackwell: Cambridge, UK, 1994; pp. 386-422.

57. Joreskog, K.G.; Sorbom, D. LISREL V, Analysis of Linear Structural Relationships by Maximum Likelihood and Least Squares Methods; University of Uppsala: Uppsala, Sweden, 1981.

58. Fornell, C.; Larcker, D.F. Evaluating structural equation models with unobservable and measurement error. J. Mark. Res. 1981, 18, 39-50. [CrossRef]

59. Bagozzi, R.P.; Yi, Y. On the evaluation of structural equation models. J. Acad. Mark. Sci. 1988, 16, 74-94. [CrossRef]

60. Baron, R.M.; Kenny, D.A. The moderator-mediator variable distinction in social psychological research: Conceptual, strategic, and statistical considerations. J. Personal. Soc. Psychol. 1986, 51, 1173-1182. [CrossRef]

61. Kumar, N.; Siddharthan, N.S. Technology, Market. Structure and Internationalization: Issues and Policies for Developing Countries; Routledge: Abingdon-on-Thames, UK, 2013.

62. Al-Hyari, K.; Al-Weshah, G.; Alnsour, M. Barriers to internationalisation in SMEs: Evidence from Jordan. Mark. Intell. Plan. 2012, 30, 188-211. [CrossRef]

63. Lee, H.O.; Park, J.S.; Choi, Y.J. Motives and strategies behind born-globals' internationalization: Cases from the culture and contents industry. Int. Manag. Res. 2007, 18, 103-139.

(C) 2016 by the authors; licensee MDPI, Basel, Switzerland. This article is an open access article distributed under the terms and conditions of the Creative Commons Attribution (CC-BY) license (http://creativecommons.org/licenses/by/4.0/). 